Environment Conservation Journal 14(3)29-32, 2013

ISSN 0972-3099 (Print) 2278-5124 (Online)

Abstracted and Indexed

\title{
Impact of water quality on the phytoplankton abundance of Paniyala fish pond in Roorkee, District Haridwar, Uttarakhand
}

\author{
D.R. Khanna, Rajni Rana $\bowtie$ and Fouzia Ishaq
}

Received: 07.6.2013

Revised: 11.08.2013

Accepted: 8.09.2013

\begin{abstract}
The phytoplankton shows an ability to tolerate a wide range of environmental conditions. Under natural condition, they usually grow in the mixed community which may include many species and genera. The phytoplankton abundance and their impact on the water quality were studied in Paniyala fish pond, located in Roorkee Uttarakhand. Samples were collected monthly from March 2007 to February 2008 at four stations early in the morning. Physico-chemical parameters like temperature, conductivity, turbidity, pH, dissolved oxygen (DO), biological oxygen demand (BOD), total alkalinity and chloride were measured simultaneously. Monthly variations were quite evident and showed maximum phytoplankton abundance in the month of January (3631.75 Unit/l). Three divisions of phytoplankton were found which include diatoms, green algae and blue green algae. The greatest number of individuals was reported in diatoms $(1610.0 \pm 909.97 \mathrm{Unit} / \mathrm{l})$ followed by green algae $(\mathbf{1 7 8 . 2 9} \pm \mathbf{1 0 9 . 0 2} \mathrm{Unit} / \mathrm{l})$ and blue green algae $(38.42 \pm 24.13 \mathrm{Unit} / \mathrm{l})$. Effects of eutrophication were evident from this study with increased biomass of phytoplankton and water quality was deteriorated to some extent resulting in threat to fish fauna in it.
\end{abstract}

Keywords: Abundance, diatoms, eutrophication, Paniyala, phytoplankton

\section{Introduction}

Water is very important for all living organisms as it has a great social and economic value ultimately affecting human health. Fresh water bodies in the form of lentic habitats like ponds, lakes and swamps come are very useful for different activities besides drinking water source. Depending upon the quality, use of water is multipurpose. Water quality is primarily based upon its physical, chemical and biological characteristics. Over exploitation of these water bodies by civilization causes deterioration of water quality. The reservoirs containing fresh water are used for fish culture, aquaculture, navigation and transport, recreation, irrigation hydropower generation and a host of such other purposes (Khanna, et al. 2012). Aquatic life is influenced directly or indirectly by the physical and chemical factors. Fluctuation in any one of the factors may create an adverse environment to the organisms, affecting their growth and life phenomena.Phytoplankton are the main primary producers in open waters, so they condition the structure and density of consumers as well as

\section{Author's Address}

Department of Zoology and Environmental Science, Gurukula

Kangri University, Haridwar

Email: drkhanna2002@gmail.com physico-chemical properties of water. Moreover, phytoplanktonic organisms are sensitive indicators, as phytoplankton structure and metabolism changes quickly in response to environmental changes (Siddiqui, et al. 1980). Algae that form the source of food and oxygen for heterotrophic organisms in aquatic habitats, directly affect primary productivity by forming first circle of food chain. The present study was conducted on the phytoplankton abundance and their impact on the water quality was studied in Paniyala fish pond, located in Roorkee Uttarakhand to investigate its current conditions and to suggest energy recovery methods.

\section{Material and methods}

Roorkee, a moderate size town in the district Haridwar is located at the bank of Ganga canal. The Paniyala fish pond is situated at the village Paniyala which is $7 \mathrm{~km}$ away fro Roorkee. The source of water in the pond is rain water and quite a bit from ground water. The Paniyala pond is at the height of 268.00 meter from the mean sea level (longitude $77^{\circ} 53^{\prime \prime} \mathrm{E}$ and Latitude $\left.29^{\circ} 51^{\prime \prime} \mathrm{N}\right)$. The maximum depth of the pond is 2.80 meter and minimum 0.60 
meter, mean depth is 1.70 meter having a surface area of 292,500 square meter.For present study of the Paniyala pond, the water samples were collected monthly from four different sampling sites during March 2007 to February 2008 in morning hours. The samples were taken in borosil glass bottles of $300 \mathrm{ml}$ and plastic cans of $1.0 \mathrm{~L}$ from each location. The collection and analysis of water samples was done using standard methods with the help of Welch (1948), Trivedi and Goel (1986), APHA (1998) and Khanna and Bhutiani (2003) for physico-chemical parameters.The phytoplankton of pond water was collected by fine plankton collection net. A known amount of water was filtered through plankton collection net and concentrated in desired quantity inside collection tube.The sample was preserved in $4 \%$ formaldehyde solution. $1 \mathrm{ml}$ of concentrate was taken and placed in Sedgwick rafter counting cell, a glass slip was placed over it avoiding any kind of bubble. Calculation of the organisms was done by applying the following formula:

\section{Calculation}

Phytoplankton $($ Unit $/ \mathrm{L})=(\mathrm{a} \times 1000) \mathrm{C} / \mathrm{L}$

Where,

a: Average number of phytoplankton in one small counting chamber of Sedgwick rafter counting cell $\mathrm{C}: \mathrm{ml}$ of plankton concentrate

L: Volume of original water filtered in litre

\section{Results and Discussion}

The data collected on physico-chemical factors during the present study is presented in table 1 . Among all factors controlling the environment of pond, temperature is one of the single, major factors having the most intense direct and indirect of effect on the water reservoir or any aquatic ecosystem. In the present study the temperature fluctuation ranged between maximum $\left(29.60^{\circ} \mathrm{C}\right)$ in the month of May and June and minimum $\left(17.63^{\circ} \mathrm{C}\right)$ in the month of December. Highly turbid water makes it difficult for fishes to see their prey but the particulate matter in the water may even actually clog their gills. The turbidity in monsoon increases in water bodies due to more run off, landslides and soil erosion in addition to the increased organic load in water from other sources. The turbidity was observed to be closely and directly related to each other, as also reported by Dutta et al. (1983a) and Khanna (1993). The water is generally clean in other season with lowest turbidity in winters. The turbidity was maximum (140.80NTU) in the month of August and minimum of (18.75 NTU) in the month of November.The water of pond was found to be alkaline during the course of study. The $\mathrm{pH}$ was maximum (8.31) in the month of May. Higher concentration of calcium in water may also increase $\mathrm{pH}$. The $\mathrm{pH}$ was recorded to be minimum (7.80) in the month of August. Similar trend have been reported by Badola (1979). However, in contrast to this, Khanna and Chugh (2004) observed higher $\mathrm{pH}$ value in winter season at Bhimgoda. Khanna (1993) also reported higher $\mathrm{pH}$ values in winter and less in rainy season. Dissolved oxygen is also an important parameter which speak of health of the water body in terms of trophic status, and also if biotic status (Nalewazko et al., 1981). For the determination of the trophic status of the water body through oxygen values, the depth wise oxygen profile is very essential but in the present study only the surface samples have been considered and hence it is not reasonable to consider dissolved oxygen values for determining the trophic status of Paniyala pond. The dissolved oxygen was found maximum of $(8.93 \mathrm{mg} / \mathrm{l})$ in the month of December and was recorded to be minimum (5.13 $\mathrm{mg} / \mathrm{l})$ in the month of May. This trend was also similar to Singh et al., (1982) in river Nayar. The biochemical oxygen demand of polluted water is purely a measure of oxygen used by a sample of water kept at $20{ }^{\circ} \mathrm{C}$ for 5 days in darkness. Thus, the estimation of BOD is an assessment of the organic load in pond ecosystem. The BOD was found to be maximum $(4.70 \mathrm{mg} / \mathrm{l})$ in the month of June and minimum of $(2.83 \mathrm{mg} / \mathrm{l})$ in the month of December. Chloride contents of a water body depicts the pollution level of organic origin, Rao (1987) reported annual average chloride contents of Ranga Sagar lake to be $83.73 \mathrm{mg} / 1$ and designated the water body as eutrophic. Chloride is one of the important indicators of water quality. During present study it was reported maximum of $(31.94 \mathrm{mg} / \mathrm{l})$ in the month of June and minimum of $(16.80 \mathrm{mg} / \mathrm{l})$ in the month of November. Chlorides get added up into the water body through sewage, domestic as well as industrial effluent and farm drainages. 
Impact of water quality on the phytoplankton abundance

Table 1: Average monthly variation in physico-chemical parameters of Paniyala fish pond from $2007-2008$

\begin{tabular}{|c|c|c|c|c|c|c|c|c|}
\hline Parameters & \multirow[t]{2}{*}{ Temperature } & \multirow[t]{2}{*}{ Conductivity } & \multirow[t]{2}{*}{ Turbidity } & \multirow[t]{2}{*}{ pH } & \multirow[t]{2}{*}{ D.O } & \multirow[t]{2}{*}{ B.O.D } & \multirow{2}{*}{$\begin{array}{l}\text { Total } \\
\text { alkalinity }\end{array}$} & \multirow[t]{2}{*}{ Chloride } \\
\hline Months & & & & & & & & \\
\hline March & 25.85 & 39.75 & 48.0 & 8.24 & 6.70 & 3.75 & 339.0 & 24.45 \\
\hline April & 27.85 & 38.00 & 78.25 & 8.27 & 5.58 & 3.93 & 330.0 & 26.77 \\
\hline May & 29.60 & 40.50 & 82.0 & 8.31 & 5.13 & 4.28 & 306.0 & 28.37 \\
\hline June & 29.60 & 40.00 & 101.0 & 8.28 & 5.38 & 4.70 & 262.0 & 31.94 \\
\hline July & 29.16 & 41.00 & 135.0 & 7.88 & 5.50 & 4.48 & 253.0 & 25.15 \\
\hline August & 27.50 & 51.75 & 140.80 & 7.80 & 5.53 & 4.20 & 341.0 & 22.14 \\
\hline September & 28.83 & 56.00 & 36.0 & 8.17 & 6.13 & 3.90 & 352.0 & 20.48 \\
\hline October & 29.33 & 82.25 & 19.75 & 8.26 & 6.15 & 3.08 & 425.0 & 18.68 \\
\hline November & 21.48 & 93.50 & 18.75 & 8.23 & 8.35 & 2.98 & 347.0 & 16.80 \\
\hline December & 17.63 & 81.75 & 22.25 & 8.23 & 8.93 & 2.83 & 341.0 & 17.25 \\
\hline January & 19.45 & 73.25 & 29.25 & 8.21 & 8.13 & 3.08 & 322.0 & 19.30 \\
\hline February & 22.45 & 59.25 & 31.50 & 8.22 & 7.60 & 3.33 & 338.0 & 21.78 \\
\hline $\begin{array}{l}\text { Avg. } \\
\text { 土S.D. }\end{array}$ & $\begin{array}{l}25.73 \\
\pm 4.33 \\
\end{array}$ & $\begin{array}{c}58.08 \\
\pm 19.87 \\
\end{array}$ & $\begin{array}{c}61.94 \\
\pm 44.66 \\
\end{array}$ & $\begin{array}{c}8.17 \\
\pm 0.16 \\
\end{array}$ & $\begin{array}{c}6.59 \\
\pm 1.33 \\
\end{array}$ & $\begin{array}{c}3.71 \\
\pm 0.64 \\
\end{array}$ & $\begin{array}{c}329.0 \\
\pm 44.20 \\
\end{array}$ & $\begin{array}{l}22.76 \\
\pm 4.69 \\
\end{array}$ \\
\hline
\end{tabular}

it remains unchanged during the purification of sewage. Some studies on different river systems like river Jhelum by Raina et al. (1984), river Yamuna by Sengar et al. (1985), river Tungabhadra by Reddy and Venkateshwarlu, (1987) also confirm the presence of chlorides.

\section{Phytoplankton of the Paniyala pond}

Aquatic life is influenced directly or indirectly by the physical, chemical and biological factors. Fluctuation in any one of the factors may create an adverse environment to the organisms, affecting their growth and life phenomena. Biological analysis of the pond water is very important because they play a very important role in maintaining the aquatic ecosystem and it is observed that in the pond water consists of different species of phytoplankton like diatoms, green algae and blue green algae. The data collected on phytoplankton during present investigation is presented in table 2. Phytoplankton was found maximum in winter and minimum in monsoon season. Out of all the families the maximum number of individuals was observed from diatoms 1610.0 \pm 909.97 (Unit/l) and minimum number of organism was from blue green algae $38.42 \pm 24.13$ (Unit/L).The total phytoplankton reported during the entire study was $1823.88 \pm 1019.10$ (Unit/l). Among total diatoms the maximum number of individuals were found in the month of January (3243.0 Unit/l) and minimum of 556.50 (Unit/l). Das (1989) concluded that abundance of diatoms in a water body is an indication of eutrophic condition. In case of green algae the number of individuals was found maximum of $350.50 \mathrm{Unit} / \mathrm{L}$ in the month of December and minimum of 34.25 Unit/L in the month of August.The number of individuals in family blue green algae was found maximum of 72.00 Unit/L in the month of December and minimum of 3.00 Unit/l in the month of July. The impact of physico-chemical factors and their relation was evident from our results. Our results were similar with the study of Khanna et al. (1997) who investigated population of green algae in relation to physico-chemical factors of river Ganga and also studied the phytoplanktonic communities in relation to certain physico-chemical parameters. The phytoplankton population in a pond was usually comprised of numerous species of microscopic plants that live in a horizontal band or zone near the water surface. The densest population is usually located in a horizontal band extending from about two to three inches below the surface to a depth of 18 to 20 inches. The depth of the band depends on numerous factors including pond turbidity, light penetration, and available plant nutrients. When the algal species in the phytoplankton community reproduce, the phytoplankton will reach a density that can be characterized as a slight cloudiness or turbidity in the water. Often, the phytoplankton population can become so dense that it will produce a deep opaque color at the pond's surface.

\section{Conclusion}

The role of planktonic organisms in an aquatic environment is an essential link in the food chain 
Khanna et al.

Table 2: Average monthly variation different groups among phytoplankton (Unit/l) of Paniyala fish pond from 2007- 2008

\begin{tabular}{|l|c|c|c|c|}
\hline Parameters & $\begin{array}{c}\text { Total Phytoplankton } \\
(\mathbf{U n i t} / \mathbf{l})\end{array}$ & $\begin{array}{c}\text { Total Diatoms } \\
(\text { Unit/l) }\end{array}$ & $\begin{array}{c}\text { Total Green Algae } \\
(\text { Unit/l) }\end{array}$ & $\begin{array}{c}\text { Total Blue Green Algae } \\
\text { (Unit/l) }\end{array}$ \\
\hline Months & 2502.0 & 2242.0 & 221.25 & 38.25 \\
\hline April & 2119.0 & 1881.75 & 177.00 & 59.50 \\
\hline May & 1620.25 & 1460.25 & 123.75 & 35.50 \\
\hline June & 854.25 & 764.50 & 71.00 & 18.25 \\
\hline July & 595.25 & 556.50 & 35.00 & 3.00 \\
\hline August & 771.75 & 781.75 & 34.25 & 22.00 \\
\hline September & 1029.25 & 891.0 & 100.75 & 35.25 \\
\hline October & 1321.50 & 1120.0 & 165.50 & 35.75 \\
\hline November & 1643.0 & 1322.50 & 286.75 & 72.00 \\
\hline December & 2274.25 & 1854.25 & 350.50 & 70.50 \\
\hline January & 3631.75 & 3243.0 & 318.00 & 65.75 \\
\hline February & 3524.25 & 3202.50 & 255.75 & $\mathbf{3 8 . 4 2 \pm 2 4 . 1 3}$ \\
\hline Avg. \pm S.D. & $\mathbf{1 8 2 3 . 8 8} \pm \mathbf{1 0 1 9 . 1 0}$ & $\mathbf{1 6 1 0 . 0 \pm 9 0 9 . 9 7}$ & $\mathbf{1 7 8 . 2 9} \pm \mathbf{1 0 9 . 0 2}$ & \\
\hline
\end{tabular}

and they are capable of affecting the entire aquatic biota. The water quality of Paniyala fish pond was deteriorated to a great extent and the algal blooms were seen in the pond making it unfit for different purposes.Existing physico-chemical characteristics of the water were not favorable for life of organisms and water body was eutrophic and pollution was clearly visible.

\section{References}

APHA (American Public Health Association) 1998. Standard method for examination of water and wastewater, 20th edition, Washington, DC, USA, P. 4.66-4.69.

Badola, S.P. 1979. Ecological studies on the Ichythofauna of some freshwater resources of Garhwal Region, D.Phil Thesis, Garhwal University.

Dutta, N.C., Bandopadhaya, B.K. and Bandopadhyaya, S.B. 1983a.Relationship between the phytoplankton and primary productivity of a freshwater pond at Calcutta. Env.Eco, (3):137

Khanna, D. R. and Chugh, T. 2004. Microbial Ecology: A study of River Ganga, Discovery publishing house, New Delhi. 1-277.

Khanna, D.R. 1993.Ecology and pollution of Ganga River, Ashish Publication House, Delhi, 1-241.

Khanna, D.R. and Bhutiani, R. 2003.Limnological characteristic of the river Ganga at Haridwar (Uttaranchal), U.P.J.Zool., Vol. 23(3): 179-183.

Khanna, D.R., Bhutiani, R., Gagan Matta, Vikas Singh and Fouzia Ishaq. 2012. Seasonal variation in physicochemical characteristic status of River Yamuna in Doon valley. Env. Cons. J., 13(1\&2): 125-128.
Khanna, D.R., Malik, D.S. and Badola, S.P. 1997. Population of green algae in relation to physico-chemcial factors of the river Ganga at Lal-Ji-Wala, Haridwar. Uttar Pradesh J. Zool. 17(3): 237-240.

Nalewazko C., Bryant, G. and Sreenivasan, M. 1981.Limnology of Heart Lake. Ontario. Hydrobiol., 79: 245-253.

Raina, V., Saha, A.R. and Ahmed, S.R. 1984. Pollution studies on river Jhelum-I: An assessment of water quality. Indian.J.Env. Health, 26:187-210.

Rao, N.G. 1987.Synecology of the lake Rangasagar in relation to the limnology and eutrophication.Ph.D. Thesis Sukhadia Univ. Udaipur.

Reddy, P.M. and Venkateshwarlu, V. 1987. Assessment of water quality and pollution in River Tungbhadra near Kurnool, (A.P.). J. Environ. Biol., 8(2):109-119.

Senegar, R.M.S., Sharma, K.D. and Pathak, P.D. 1985. Studies on distribution of algal flora in polluted and non polluted regions in Yamuna River at Agra (U.P.). J. Indian Bot. Soc., 64:365-376.

Siddiqui, E.N., Singh, N.K. and Afsar, N.R. 1980. Primary production studies in a freshwater pond at Barauni, Bihar (India). Comp. Physiol ecol., 5(4): 258-260.

Singh, H.P., Chaudhry, M. and Kalekaur, V. 1982. Seasonal and diurnal changes in physico-chemcial features of the river Brahamputra at Gauwahati, Ind. J. Zool., 2(82):7784.

Trivedi, R.K. and Goel, P.K. 1986. Chemical and biological methods for water pollution studies. Environmental publications, Karad: 1-250 pp.

Welch, P.S. 1948.Limnological Methods, the Blakiston. Co. Philadelphia, 1-381. 